\title{
Aspecte ale relevanței în discursul politic românesc
}

\author{
Ana Ene* \\ Facultatea de Litere, Universitatea Transilvania din Braşov, Bd. Eroilor 29, 500036 Brașov, România
}

\section{Despre articol}

Istoric:

Primit 12 august 2018

Acceptat 30 august 2018

Publicat 7 mai 2019

Cuvinte-cheie:

retorică

stilistică

sociolingvistică

\begin{abstract}
Rezumat
Această lucrare investighează discursul politic din perspectiva teoriei relevanței în raport cu funcția de persuasiune rezonabilă orientată spre alegători. Obiectivele cercetării sînt identificarea și descrierea 1) mecanismelor de convingere utilizate în discursurile campaniei electorale, 2) a metastrategiei de mimare a dialogului și 3) a modului în care discursul politic încalcă principiile relevanței. Realizarea obiectivelor necesită o metodologie cu două dimensiuni-retorică și lingvistică—prin intermediul unor instrumente de analiză logico-argumentativă, lexico-semantică și pragmastilistică. Cercetarea este axată pe discursurile campaniilor electorale politice: sloganuri și discursuri ale campaniilor electorale recente din România.

Strategiile discursive cel mai frecvent întîlnite sînt: i) utilizarea diferitelor tipuri de raționament falacios și ii) limbajul vag.
\end{abstract}

\section{Introducere}

Subiectul acestei lucrări este discursul politic românesc din perspectiva teoriei relevanței (Sperber \& Wilson, 1995). O conturare a acestui domeniu de investigare implică anumite abordări ale retoricii discursului de propagandă, în general, și ale discursului politic, în particular. Cercetarea se concentrează pe discursurile politice din campaniile electorale. Corpusul cuprinde în principal sloganurile și discursurile protagoniștilor politici implicați în campania electorală pentru alegerile parlamentare din 11 decembrie 2016 și în alegerile locale din 5 iunie 2016. Sînt luate în considerare atît formele de promovare a campaniilor politice de tip outdoor, cît și de tip indoor, precum și cîteva fragmente de discursuri performate la diverse adunări sau în interviuri de televiziune.

Obiectivele cercetării sînt următoarele: 1) identificarea și descrierea mecanismelor diferitelor strategii de persuadare utilizate de politicieni în discursul de campanie electorală; 2) identificarea și descrierea procedeelor implicate de metastrategia mimării dialogului în acest tip de discurs; 3) identificarea și descrierea modului în care strategiile sus-menționate încalcă principiile relevanței.

Dimensiunea retorică a metodologiei reclamate de obiectivele menționate mai sus implică unele elemente de analiză logico-argumentativă. De asemenea, avînd în vedere necesitatea de a lua în considerare contextul și parametrii situației enunțării care sînt specifici discursurilor analizate, va fi obligatorie recurgerea la instrumentele furnizate de analiza lexico-semantică și de cea pragmastilistică. Metodologia dublu dimensionată se bazează pe „o corelație între resursele pragmatice și retorice ale construirii vorbirii”. Aceasta se datorează faptului că seriile de categorii structurale aparținînd pragmaticii și, respectiv, retoricii „distribuie în paralel aceleaşi resurse lingvistice” (Ionescu-Ruxăndoiu, 2007, p. 313).

Principala ipoteză este că principiile cognitive și comunicative ale relevanței sînt adesea încălcate în discursul politic, în general, și în discursul de campanie, în special. Prin urmare, raportul dintre relevanță și comprehensiune este luat în considerare numai în concordanță cu parametrii formali, dar încălcat în substanţă. Este clar că intenția comunicativă nu este menită să furnizeze alegătorilor informații corecte pentru a asigura o deschidere către reflexia rezonabilă, ci pentru a-i convinge valorificîndu-se componenta

*Adresă de corespondență: enea@unitbv.ro. 
emoțională prin prezentarea unor fapte subiective sub forma unor date obiective. În prezentarea distorsionată a faptelor, strategiile cel mai frecvent întîlnite sînt: i) utilizarea masivă a argumentelor de tip ad verecundiam $^{1}$, ad hominem ${ }^{2}$ și ad ignorantiam ${ }^{3}$ în locul argumentelor de tip ad judicium ${ }^{4}$, ii) raționamentul falacios și iii) limbajul vag sau, dimpotrivă, limbajul aparent plauzibil, bazat pe date, surse, figuri etc. Mai mult decît atît, o metastrategie este cea a mimării dialogului cu alegătorii prin diferite tehnici retorico-stilistice. Receptorul este atras într-un fel de complicitate comunicațională, care se bazează adesea pe ipoteze false, cu o intenție clară de a converti acordul receptorului (care este deja implicat în declarații, idei și în interpretările respectivei figuri politice discursive) într-un vot favorabil.

\section{Relevanța și discursul politic}

Încă într-o fază preliminară a analizei elementelor corpusului, au apărut cîteva întrebări. Răspunsurile la aceste întrebări au scopul de a clarifica contextul general în care discursurile sau fragmentele de discurs analizate sînt realizate. Pe de altă parte, este important să înțelegem modul în care se dezvoltă procesul de influențare a publicului prin discursul politic.

\subsection{Cîteva întrebări și cîteva răspunsuri}

Așadar, cine spune ce, unde, cînd și cum? Care sînt contextele situaționale? Pentru a reduce discrepanța comunicativă sau, cu alte cuvinte, pentru facilitarea jocului de acțiune comunicativ (Plett, 1983), o receptare pragmatică adecvată a elementelor corpusului analizat necesită nu numai indicarea parametrilor situației enunțării (cine, ce, unde, cînd, cum), ci și o descriere succintă a contextului situațional (evenimente politice interne, fapte și evenimente, mai mult sau mai puțin recente, evocate în discursurile supuse analizei).

Cum, în ce măsură și de ce anume este influențată interpretarea de către receptor a discursului politic? Într-adevăr, „[...] un context nu este dat o dată pentru totdeauna, ci este construit, enunțare după enunțare, de către interlocutor, pe baza informațiilor provenite din diferite surse și pe baza principiului pertinenței” (Sperber \& Wilson, 1995). Dar totul începe de la intenție: dacă intenția este de a manipula, atunci conceptul de pertinență discursivă este corupt de la început. Din păcate, foarte des, relevanța devine irelevantă în discursul politic.

Relevanța (sau pertinența), conceptul central al teoriei relevanței (Sperber \& Wilson, 1995), reprezintă ansamblul efectelor obținute la sfirșitul procesului de interpretare și al eforturilor de procesare în cursul acestui proces. Esența principiului pertinenței / relevanței este că orice enunțare trebuie să ofere o asigurare a pertinenței (Sperber \& Wilson, 1995, p. 83). În conformitate cu acest principiu: (i) o enunțare va fi cu atît mai pertinentă, cu cît produce mai multe efecte contextuale; (ii) o enunțare este cu atît mai relevantă, cu cît necesită mai puține eforturi de procesare. Eforturile de prelucrare aparţin, evident, receptorului, dar politicienii (autorii discursurilor) doresc ca receptorul să fie ghidat spre efectele pe care ei le așteaptă.

Pe de altă parte, intenția comunicativă constă în „a face [ca aceasta] să se manifeste reciproc pentru public și comunicator atunci cînd comunicatorul are această intenție informativă” (Sperber \& Wilson, 1995, p. 61). Bineînțeles, autorii invocați vorbesc despre intenția autentică de comunicare. Aici trebuie să ne punem o altă întrebare: relevanța enunțurilor politice servește unei intenții de comunicare autentice (în termenii lui Sperber \& Wilson) sau, invers, unui proces persuasiv care are intenții complet diferite? Desigur, este o întrebare retorică...

${ }^{1}$ Ad verecundiam este un mod de argumentare care folosește respectul adversarului pentru opinia unei persoane sau a mai multora care și-a(u) cîștigat reputația în ochii opiniei comune (prin cultura, distincția, puterea și facultățile intelectuale); respingerea duce la clasificarea adversarului ca persoană arogantă și disprețuitoare.

${ }^{2}$ Argumentul ad hominem constă în încolțirea interlocutorului cu consecințele trase din propriile sale principii sau mărturisiri.

${ }^{3}$ Argumentul ad ignorantiam implică faptul că interlocutorul ori recunoaște opinia vorbitorului, ori este somat să ofere o soluție mai bună.

${ }^{4}$ Ad judicium este modul de argumentare care utilizează dovezile extrase din anumite surse ale cunoașterii sau ale probabilităţii. 
De aceea, sarcina noastră va fi să denunțăm acele strategii prin care relevanța este coruptă de o intenție de comunicare manipulatoare a discursului politic. Iar aceste strategii sînt și mai proeminente în discursul politic al campaniilor electorale.

\subsection{Despre condițiile extensive ale relevanței}

Potrivit lui Sperber \& Wilson (1995, p. 125), pentru a obține o enunțare cu un grad ridicat de relevanță, eforturile de procesare a informațiilor pot fi reduse printr-o producție crescută de efecte contextuale. Astfel, autorii consideră că definiția relevanței poate fi îmbunătățită prin adoptarea a două condiții:

Condiția extensivă 1: o ipoteză este relevantă într-un context în măsura în care efectele sale contextuale în acest context sînt mari.

Condiția extensivă 2: o ipoteză este relevantă într-un context în măsura în care efortul necesar procesării acesteia în acest context este mic.

Această definiție angajează condiția necesară și suficientă de definire $(7)^{5}$, care, prin urmare, nu trebuie să fie specificată în mod independent.

Efectele contextuale sînt produsul interpretării enunțurilor în raport cu un context specific și pot fi obținute în trei moduri: (1) adăugarea de informații, (2) suprimarea de informații, (3) intensificarea forței cu care o aserțiune este menținută.

Autorii formulează o întrebare și tot ei oferă şi răspunsul: „ar putea fi definită relevanța nu doar ca un concept comparativ, ci ca un concept cantitativ? Răspunsul nostru este: da, ar putea" (Sperber \& Wilson, 1995, p. 125).

Într-adevăr, urmărind un exemplu dat de Sperber \& Wilson, 1995, p. 109), putem vedea cum crește relevanţa unei ipoteze prin producerea de informații suplimentare:

(81) (a) If Peter, Paul and Mary came to the party, the party was a success.

[Dacă Peter, Paul și Mary au fost la petrecere, petrecerea a fost un succes.]

(b) Peter came to the party.

[Peter a fost la petrecere.]

(c) Paul came to the party.

[Paul a fost la petrecere.]

(d) Mary came to the party.

[Mary a fost la petrecere.]

(82) The party was a success.

[Petrecerea a fost un succes.]

Putem observa că premisele suplimentare (b), (c), (d) simplifică orice potenţial efort cognitiv al receptorului de înțelegere a enunțului (81). Aceste premise suplimentare sînt parţial incluse în condiția formulată în (81). În final, enunțarea (82) subliniază a doua parte a ipotezei (81).

Exemplul celor doi autori poate fi prelucrat astfel încît să ilustreze celelalte două modalități de a obține efecte contextuale.

Prin urmare, suprimarea informațiilor implică lipsa condițiilor (b), (c), (d):

(81) (a) If Peter, Paul and Mary came to the party, the party was a success.

[Dacă Peter, Paul și Mary au fost la petrecere, petrecerea a fost un succes.]

(82) The party was a success.

[Petrecerea a fost un succes.]

${ }^{5}$ „[Relevanța arată că] O ipoteză este relevantă într-un context dacă și numai dacă are un efect contextual în acest context” (Sperber \& Wilson, 1995, p. 122). 
În acest caz, receptorul trebuie să facă un efort minim pentru a înțelege enunțul (81). Ajutați de enunțarea (82), receptorul trebuie să presupună că a fost îndeplinită condiția exprimată: atît Peter, Paul, cît și Mary au fost la petrecere.

De asemenea, un efect contextual poate fi obținut prin introducerea unui intensificator.

(a) If Peter, Paul and Mary came to the party, the party was a success.

[Dacă Peter, Paul și Mary au fost la petrecere, petrecerea a fost un succes.]

(82) The party was a real success.

[Petrecerea a fost un real succes.]

Intensificatorul real simplifică efortul cognitiv al receptorului de a înțelege enunțarea (81): asta înseamnă cu siguranță că Peter, Paul și Mary au fost la petrecere.

Dacă „este suficient de ușor să identificăm o varietate de factori care ar face posibilă predictibilitatea informațiilor care vor avea cele mai mari efecte contextuale" (Sperber \& Wilson, 1995, p. 131), este de la sine înțeles că politicienii-din păcate, o mare parte dintre ei-exploatează acest principiu nu pentru o comunicare relevantă de informații, ci pentru transmiterea unor informații gata livrate, avînd inclusă interpretarea.

Aspectele comunicării verbale sînt rezumate de Sperber \& Wilson (1995, p. 232) în felul următor: „Forma propozițională a unei rostiri este o interpretare a reprezentării mentale a vorbitorului care poate fi tratată ca o interpretare [sau] ca o descriere”. Putem avea o interpretare a unei „reprezentări reale (de exemplu, atribuită)” sau a unei „reprezentări dorite (de exemplu, relevantă)”. Descrierea se poate referi la „o stare de lucruri reală” sau la „o stare de lucruri dorită”.

În special în campaniile electorale, politicienii aproape întotdeauna recurg la utilizarea interpretativă a reprezentării în detrimentul utilizării descriptive, deși aceasta din urmă corespunde în realitate misiunii lor: să-și prezinte propriile platforme politice. Astfel, sarcina receptorilor este dublă. În primul rînd, contextul aserțiunii/aserțiunilor trebuie restabilit și numai după aceea informațiile pot fi prelucrate în scopul unei interpretări personale. Desigur, în acest moment al discuției, nu trebuie să luăm unilateral conceptul de subiectivitate. Catherine Kerbrat-Orecchioni (1980, p. 32) face o observație pertinentă cu privire la competența partenerilor într-o situație de comunicare. Competența comunicativă a partenerilor implică o serie de „imagini”: imaginea fiecăruia despre sine, imaginea fiecăruia despre celălalt și posibila imagine de sine în fiecare conștiință a celorlalți. În consecință, în practica discursivă, nu ne adresăm destinatarului real, ci celui construit de subiectivitatea noastră, iar destinatarul decodifică mesajul în funcție de ceea ce crede că știe despre emițător. Aceasta este miza în discursul politic de campanie: politicienii încearcă să-și construiască imaginea în aşa fel încît alegătorii să nu mai poată ajunge la imaginea reală.

\section{Alegerile parlamentare românești din 11 decembrie 2016}

În cele ce urmează, se va vedea modul în care politicienii reușesc să realizeze efecte contextuale considerabile într-un mod care reduce efortul de procesare a mesajului de către receptor spre o anumită interpretare. Dar, mai întîi, să vedem contextul general.

Această campanie electorală a fost caracterizată de lipsă de inspirație, nu au existat dezbateri între candidații importanţi și s-a desfășurat într-o atmosferă marcată de o apatie și un non-combat care au fost în mod clar în beneficiul PSD $^{6}$-ului. Principalele grupări politice au fost PSD și ALDE ${ }^{7}$, impreună față de $\mathrm{PNL}^{8}$. Candidatul PNL a fost sprijinit de USR ${ }^{9}$, o nouă formațiune politică. În opoziție cu toate acestea, a fost $\mathrm{PMP}^{10}$, partid condus de fostul președinte al României, Traian Băsescu.

\footnotetext{
${ }^{6}$ Partidul Social Democrat.

${ }^{7} \mathrm{O}$ formațiune politică eclectică (o fracțiune detașată din PNL plus politicieni proveniți din alte partide).

${ }^{8}$ Partidul Național Liberal.

${ }^{9}$ Uniunea Salvați România.

${ }^{10}$ Partidul Mişcarea Populară.
} 
Adversarii politici au recurs în mod repetat la atacuri la persoană, dar nu au aplicat lovituri capitale ca în alte campanii. Poate că singura lovitură „sub centură” a fost dezvăluirea publică a salariului primit de la UE de către candidatul PNL (Dacian Cioloș). Astfel, după cum au remarcat analiștii politici, o temă de campanie emoțională a PNL („salariile și pensiile nemeritate” ale unor categorii privilegiate de sistemul PSD) a fost anulată din cauza unui potențial efect de bumerang.

PSD a avut o campanie sobră. Liviu Dragnea, președintele PSD-ului, a recomandat candidaților săi: „Nu facem mitinguri, nu organizăm spectacole, nu aruncăm confetti în aer”. Așa că, social-democrații au popularizat asiduu programul guvernamental în care au promis o avalanşă de creșteri salariale și reduceri de impozite. Liberalii au început cu greu lupta politică și au mizat pe imaginea premierului Dacian Cioloș, încă în funcție. Dar se pare că a fost o mișcare neinspirată. PSD a cîștigat alegerile și a format majoritatea parlamentară împreună cu ALDE și apoi guvernul.

\subsection{Bătălia sloganurilor}

În general, sloganurile țintesc efectele contextuale generate de modul de suprimare a informațiilor, dar folosesc și diverse forme de intensificare. Aceasta este, în esență, natura sloganului, care trebuie să fie concis pentru a fi memorabil. Cît de inspirat este, aceasta este cu siguranță o altă problemă.

Sloganul PSD-ului, „Îndrăznești să crezi în România!”, este o continuare a celui dintr-o campanie anterioară: „Mîndri că sîntem român!”. De fapt, alegătorii sînt invitați să creadă în PSD, partidul care se declară a fi singurul care poate transforma România într-o țară în care poporul român poate trăi mai bine decît înainte. Este un discurs incitativ, care se bazează pe partea naționalistă a electoratului, provenind, în special din zonele rurale și cu probleme sociale, ceea ce înseamnă bazinul electoral tradițional al PSD-ului.

Președintele partidului și-a îndemnat candidații astfel:

Candidați pentru oamenii pe care doriți să-i reprezentați. Ceea ce vă caracterizează pe toți, [...] și pe marea masă a PSD-ului este dragostea de oameni. [...] Acest lucru m-a ajutat și pe mine să realizez acest program de dezvoltare care începe să-și arate roadele, program [...] care a fost criticat [...], pentru că pentru prima dată cineva din Guvern s-a gîndit la cele aproximativ nouă milioane de români care trăiesc în satul românesc. [...] Vreau, de asemenea, să vă rog, de fapt, să vă cer să mergeți cu încredere în aceste alegeri. Da, așa este, sîntem ținta tuturor.

(Liviu Dragnea, președintele partidului, la lansarea candidaților PSD-ului, 15.04.2016) ${ }^{11}$

Putem vedea exploatarea palierului emoțional („Ceea ce vă caracterizează pe toți, [...] și pe marea masă a PSD-ului este dragostea de oameni”), dar și victimizarea, o strategie frecvent utilizată de acest lider („acest program de dezvoltare care începe să-şi arate roadele, program [...] care a fost criticat [...]” și „Da, așa este, sîntem ținta tuturor”).

În plus, încă de la lansarea candidaților la alegerile locale, Liviu Dragnea a recomandat:

E o echipă pe care o cunosc, nu sînt oaspete aici! Am înțeles că oaspete astăzi în județ e Băsescu: la cîrciumă, unde să fie în altă parte? Mi-a dat un SMS cineva, un coleg, ieri dacă, ținînd cont de faptul că vine Băsescu aici, mai ținem noi conferința. Păi cum să n-o ținem? Eu nu-mi aduc aminte ca vreunuia dintre noi să-i fi fost frică de Băsescu vreodată cînd era președinte, în frunte cu mine.

$(\text { Liviu Dragnea) })^{12}$

Din punct de vedere retoric, aici avem indubitabil un atac la persoană față de fostul președinte al României, Traian Băsescu („la cîrciumă, unde să fie în altă parte?”). Putem vedea o atitudine beligerantă, care a fost însoțită de elemente paraverbale; vorbitorul se comportă ca un bătăuș în curtea școlii: „Eu nu-mi aduc aminte ca vreunuia dintre noi să-i fi fost frică de Băsescu vreodată cînd era președinte, în frunte cu mine”.

\footnotetext{
${ }^{11}$ psd.ro, accesat în 24 iulie 2017.

12 psd.ro, accesat în 24 iulie 2017.
} 
Acesta este un veritabil argumentum baculinum (din lat., „argumentul bățului”13). Mai multe tipuri de etos individual au fost discutate în literatura de specialitate (de exemplu, Charaudeau, 2005, p. 113-114): etosul umanității și al justiției, etosul caracterului și al fermității și etosul seriozității și al competenței. Acest lider, în absența unei cauze (politice) mai bune, își declară fermitatea și firea neînfricată în raport cu un alt lider de partid. În ciuda intenției de a minimiza adversarul, efectul poate fi opus, deoarece bunul-simț spune că, dacă în mod repetat acorzi prea multă atenție unei persoane, alții ar putea crede că iții este frică de acea persoană.

Sloganul PNL-ului a fost „România înainte!”. Aici putem detecta un joc de cuvinte bazat pe omofonia adverbului înainte, care nu are doar semnificația de îndemn spațial de „a înainta, a merge în față”, dar și pe aceea modală de "mai presus de orice altceva” (deci, România trebuie să fie pe primul loc în mintea noastră). Dacă virgula ar fi fost folosită după substantivul propriu (obligatorie după un substantiv în vocativ), semnificația adverbului ar fi fost redusă la cea de îndemn spațial. Această semnificație rămîne predominantă, aşa cum chiar candidatul PNL-ului explică:

Aș încheia spunînd că unii oameni spuneau că vor România înapoi. Eu cred că, mai mult ca oricînd, avînd România noastră, asumîndu-ne, e bine să vedem o Românie înainte.

(Dacian Cioloș, la lansarea candidaților PNL-ului, 6.11.2016) ${ }^{14}$

Este evident că vorbitorul exploatează antonimia dintre înapoi și înainte. La lansarea candidatului PNL la alegerile prezidențiale (Klaus Iohannis, președintele în exercițiu), purtătorul de cuvînt al PNL-ului, Alina Gorghiu, a reciclat expresia „a-și lua țara înapoi”, care a fost folosită după eșecul referendumului privind destituirea fostul președinte Băsescu. Ea a spus: „îl lansăm astăzi pe cel care va fi președintele României pentru 10 ani! Vom cîștiga, nu am niciun fel de îndoială! Ne vrem România înapoi!” ${ }^{15}$.

Sloganul USR a fost „În sfirșit, ai cu cine!”. Acesta este un joc bazat pe o aluzie. În aproape toate campaniile pentru alegerile parlamentare sau chiar prezidențiale, s-a spus că, de fapt, alegătorii au ales dezastrul mai mic (bineînțeles, dezastrul se referă la candidați). Acum, avem cu cine, candidatul susținut de USR (cel propus de PNL) merită votul nostru. În fine, trebuie să observăm și valoarea expresivă a locuțiunii adverbiale în sfirșit, care sugerează sentimentul de ușurare al votanților că blestemul alegerii răului mai mic a dispărut.

Sloganul PMP a avut o valoare puternic incitativă: „Luptă pentru România!”. Verbul a lupta, folosit la imperativ, are o valoare expresivă care transmite hotărîre, implicare.

Ca o observație generală, cu excepția sloganului USR, substantivul România este folosit în toate celelalte. Este evident că aceeași ipoteză poate fi înțeleasă în mod diferit fără un context sau o argumentare clară. Prin urmare, pentru a se stimula o reacție adecvată, singura modalitate de a direcționa diferiți receptori către aceeași interpretare este selectarea imaginilor conforme cu principiul intersubiectivității. Aceste sloganuri se bazează pe următoarele presupoziții: dacă trăiți în România și aveți drept de vot, sînteți român; prin urmare, aveți obligația de a lupta pentru țara voastră, de a contribui la progresul său sau, pur și simplu, de a fi mîndru că îi aparțineți.

\section{Discursuri și strategii}

Politicienii români, cu rare excepții, nu au învățat încă să vorbească în termeni concreți, ocolind problemele mai tehnice și subiectele jenante pentru ei, poate pentru că nu au nimic de spus. În schimb, au învăţat cum să exploateze filonul emoțional, unii dintre ei mai bine, alții mai puțin bine sau chiar căzînd în ridicol.

Acest lucru se întîmplă deoarece, mai nou, politicienii fac 'politică' (a lor), nu comunică. Cînd nu au nimic (important) de spus, atunci dramatizarea, mimarea dialogului, limbajul vag intră în joc. Omul

\footnotetext{
${ }^{13}$ Într-un registru ironic, aceasta însemnînd utilizarea forței (atacul la persoană) în locul oricărui argument.

${ }^{14}$ antena3.ro, accesat în 27 iulie 2017.

15 ziare.com, accesat în 27 iulie 2017
} 
politic se transformă într-un om de spectacol; astfel, nevoia de spectacol reduce un posibil dialog real cu alegătorii și substituie captatio cu monstratio (Charaudeau, 2005, p. 48). Acest tip de dramă socială exclude adesea o argumentare corectă și implică tot felul de aspecte frontale: confruntarea (personal front), scenariul (setting), aparența (appearance) sau abordarea (manner), potrivit lui Goffman (2007, p. 30-31).

O definiție bazată pe sintetizarea literaturii de specialitate despre limbajul vag $(\mathrm{VL})$ o oferă Green (2013, p. 16): „VL este un set de forme lingvistice pe care oamenii le folosesc pentru a tempera acuratețea, certitudinea, claritatea sau specificitatea unei declarații”. Prolixitatea („o provocare pentru receptori, care nu înțeleg ce încearcă să spună vorbitorul”), complexitatea („Cînd un vorbitor emite o argumentație greu de urmărit sau o descriere încîlcită”) și ambiguitatea („Un cuvînt sau o expresie este ambiguu atunci cînd poate însemna mai multe lucruri”) sînt principalele caracteristici ale VL (Green, 2013, p. 14). La urma urmei, s-ar putea spune că vagul este unul dintre atributele de bază ale limbajului natural. Cu toate acestea, în discursul politic, vagul apare fie ca o formă de manipulare, fie ca o expresie a incapacității și a indolenței vorbitorului. În ambele cazuri este o lipsă de respect față de alegători și față de sarcina reală a politicianului. Politicienii ar trebui să respecte acel „contrat parole” (Charaudeau, 1983), un contract care implică anumite modalități lingvistice: corectitudinea (nu numai gramaticală), fluența, concizia și claritatea.

Metaforele sînt, de asemenea, forme ale vagului, adesea folosite în loc de argumente, care nu sînt permise în astfel de comunicări, deoarece:

Vom considera o figură ca argumentativă dacă, ducînd la o schimbare de perspectivă, utilizarea acesteia pare normală în raport cu noua situație sugerată. Dacă, dimpotrivă, discursul nu implică adeziunea ascultătorului la această formă argumentativă, această figură va fi percepută ca un ornament, ca o figură de stil.

(Perelman \& Olbrechts-Tyteca, 1992, p. 229) ${ }^{16}$

Să începem seria de exemple cu un eșantion benign de propagandă politică:

Aveți de optat pe 11 decembrie, pentru voi şi pentru copiii voștri, între o țară proeuropeană irevocabil, o țară care susține NATO, o țară care susține justiția, şi o țară care rămîne în bătaia vintului rece din Est.

(Dragoș Pâslaru, la mitingul electoral regional PNL din Iași, a cărei temă a fost „Moldova se (idică” $)^{17}$

Observăm un dialog mimat („aveți de optat”) și exploatarea sentimentului datoriei față de copii („pentru copiii voștri”) ca un alt element de persuasiune. Reluarea anaforică a substantivului țară devine o oportunitate de a aduce noi determinanți, cum ar fi: „pro-europeni”, „care susțin” și, bineînțeles, intensificatorul „irevocabil”. Dar nu aflăm prin ce măsuri „,irevocabile” intenționează PNL să facă din România „o țară pro-europeană”, „o țară care sprijină justiția” și aşa mai departe. Antiteza este de asemenea folosită: spre deosebire de România oferită de PNL, apare o Românie oferită de oponenții săi politici, „o țară care rămîne în bătaia vîntului rece din Est”. Evident, metafora „vîntului rece din Est” se referă la influența Rusiei.

Un alt politician aduce argumentul propriului său exemplu:

Bună seara, Iași! Bună seara, Moldova! Sînt primarul municipiului Bîrlad, vin din Țara de Jos a Moldovei și vă transmit salutul bîrlădenilor, de unitate, forță și determinare. Am cișstigat în iunie 2016 primăria municipiului Bîrlad, într-un județ în care PSD-ul domină viaţa politică, de la Revoluție pînă în prezent. Am cîștigat acolo unde nimeni nu mai credea în noi și totuși am

\footnotetext{
${ }^{16}$ În original: „Nous considérerons une figure comme argumentative si, entraînant un changement de perspective, son emploi paraît normal par rapport à la nouvelle situation suggérée. Si, par contre, le discours n'entraîne pas l'adhésion de l'auditeur à cette forme argumentative, la figure sera perçue comme ornement, comme figure de style".

17 adevarul.ro, accesat în 25 iulie 2017.
} 
reușit. Dacă la Bîrlad am reușit, dragi liberali, înseamnă că putem cîștiga și la Iași, și la Bacău, și la Focşani, şi la Galați, și la Bucureşti, şi oriunde în România sînt liberali, uniți si determinați. [...] ar fi păcat, dragi liberali, ca 1 Decembrie 2018 să nu ne găsească la guvernare, atunci cînd noi vom sărbători 100 de ani de la Marea Unire. Unire pe care au făcut-o liberalii, prin primul ministru Ion I. C. Brătianu. Cu liberalii, înainte!

(Dumitru Boroș, primarul Bîrladului, cu aceeași ocazie ca mai sus) ${ }^{18}$

Deoarece această victorie s-a întîmplat într-o parte a țării ,în care PSD-ul domină viața politică, de la Revoluție pînă în prezent”, valoarea exemplului este și mai puternică. De asemenea, putem vedea o anadiploză („[...] Unire. Unire pe care au făcut-o [...]”) și diferitele forme de paralelism sintactic utilizate foarte des în acest tip de discurs propagandistic. Mai mult, dacă membrii PSD, adesea asociați cu fostul Partid Comunist Român, nu fac apel la istorie, dimpotrivă, vorbitorii liberali recurg adesea la acest procedeu al evocării pentru a evidenția originile și valorile istorice ale partidului lor („Unire pe care au făcut-o liberalii, prin primul ministru Ion I. C. Brătianu”).

Exemplul următor este un caz în care este necesară o minimală reconstituire a contextului enunţării. Mă refer în special la datele vorbitorului. Leonardo Badea este un tînăr membru al PSD-ului, în vîrstă de 20 de ani, care nu este bine cunoscut nici în domeniul său profesional, nici în alte domenii. Cu toate acestea, el a fost promovat în politică. Să-l vedem în acțiune:

M-am simţit întotdeauna și am fost copil al partidului. Am fost ceea ce dumneavoastră aţi hotărît să fiu: președinte la TSD Dîmbovița. Tot cu sprijinul dumneavoastră am ajuns cel mai tînăr consilier județean, tot cu sprijinul dumneavoastră am ajuns în Parlamentul României [...], tot cu sprijinul dumneavoastră am ajuns vicepreședinte al CJ Dîmbovița și am încercat pe cît posibil să vă dezamăgesc și să onorez încrederea și speranța pe care dumneavoastră aţi pus-o în mine [...] (Leonardo Badea, membru al Tineretului PSD-ist, la lansarea candidaților PSD din județul Dîmbovița pentru Camera Deputaților $)^{19}$

Fragmentul extras pare a fi o versiune Copy and Paste dintr-un celebru discurs oratoric, mai exact exordiul discursului lui Cicero în apărarea lui Roscius din Ameria:

Cred că vă mirați, judecători, de ce, atunci cînd atîți oratori şi oameni dintre cei mai de seamă șed locului, m-am ridicat eu, mai degrabă, care nici prin vîrstă, nici prin talent, nici prin autoritate nu mă pot compara cu ei... [Dar] pe lîngă mine au stăruit persoane care atît prin prietenia lor, cît şi prin binele făcut mie şi prin numele lor au mare preț în ochii mei; bunăvoința lor față de mine eram dator să nu o uit, autoritatea lor să nu o nesocotesc, dorința lor să nu o trec cu vederea.

(Cicero, Pro Roscio Amerino, I; în Mihai, 1998, p. 191)

Cicero avea doar 23 de ani, provenea din clasa de mijloc, era cunoscut drept studios și cam atît. Se pare că nu era foarte atrăgător, dar latina lui era impecabilă și melodioasă. În pofida acestor premise nu tocmai favorabile pentru tînărul care vorbea pentru prima oară în fața unui auditoriu obișnuit cu prezențe ilustre, Cicero a reușit să capteze atenția şi bunăvoința prin tonul său moderat, dar ferm. De asemenea, el și-a enumerat indirect meritele deja cunoscute unor oameni celebri, apreciaţi de public.

Tînărul membru PSD pare să încerce să exploateze nu aceleași premise, ci mai ales modelul discursiv. Evident, rezultatul este mai curînd depășit în formă și performanță. Oricum, pentru iniţiați, modelul este uşor de recunoscut. În ceea ce privește efectul rîvnit de tînărului politician, putem doar să-l cităm pe Quintilian ${ }^{20}$ : „Fără daruri naturale, regulile tehnice sînt inutile” (1974, p. 26).

Voi încheia această serie de exemple cu un fragment dintr-un discurs care nu a fost performat în campania electorală din 2016, dar care este relevant pentru maniera argumentativă politică:

\footnotetext{
18 vremeanoua.ro, accesat în 25 iulie 2017.

19 tvpartener.ro, accesat în 25 iulie 2016.

${ }^{20}$ În prefața la Institutio Oratoria, vol. I.
} 
Am dori să-l întrebăm pe domnul prim-ministru desemnat Călin Popescu-Tăriceanu dacă aceștia sînt miniștrii cei mai buni pe care Alianța îi poate oferi. Dacă nu, e grav, dacă da, e şi mai grav. Eu mai sper încă că e vorba de o farsă, un exerciţiu de imagine, o testare a atmosferei, şi că atunci cînd vom fi toți supărați, va apărea adevăratul prim-ministru, domnul Traian Băsescu, cu adevăratul guvern, așa cum ne-a promis la toți.

(Victor Ponta, în Adunarea reunită a Camerelor Deputaților și a Senatului, 28.12.2004) 21 $^{21}$

Fragmentul are două părți: un silogism („Am dori [...], e și mai grav”) și comentariul ironic facilitat de acesta („Eu mai sper încă [...], aşa cum ne-a promis tuturor”). Argumentarea în prima parte este una apagogică, deoarece vorbitorul încearcă să-și valideze propria teză contrazicînd teza interlocutorului.

Silogismul se bazează pe un argument ad hominem și pe un raționament entimemic falacios: vorbitorul încearcă în mod deliberat să ofere aspectul deducerii corecte a tezei din premisele evitate, considerate deja înțelese. Așadar, avem un raționament cu variante graduale care conduc la aceeași teză neformulată. Voi combina cele două variante $(1,2)$ în silogismul prezentat schematic mai jos:

$\mathrm{P}_{\mathrm{M}}<$ (1) Dacă nu [sînt cei mai buni miniștri ai Alianței] sau (2) (2) Dacă sînt [cei mai buni] > $\mathrm{P}_{\mathrm{m} 1}<$ [atunci] (1) e grav sau (2) essi mai grav >

$\mathrm{P}_{\mathrm{m} 2}<$ [deoarece oricine poate vedea că aceștia nu sînt miniștri buni] $>$

$\mathrm{T}<$ [Deci], (1) [primul ministru nu este capabil să facă guvernul] sau (2) [primul ministru nu are cu cine să formeze un guvern] >

unde,

$\mathrm{P}_{\mathrm{M}}$ - o premisă majoră, parțial formulată (vorbitorul imaginează un răspuns în locul persoanei somate să răspundă la întrebare);

$\mathrm{P}_{\mathrm{m} 1}$ - o premisă minoră, parțial formulată (fără conectorul atunci);

$\mathrm{P}_{\mathrm{m} 2}$ - o premisă minoră neformulată (evitată, considerată deja înțeleasă);

T - o teză neformulată (evitată, considerată deja înțeleasă).

Este clar ce decurge de aici: o altă teză neformulată, anume că Alianța nu merită să guverneze, fie pentru că nu este capabilă să desemneze un prim-ministru eficient pentru formarea guvernului, fie pentru că, oricine ar fi prim-ministru, acesta nu are nicio șansă să recruteze miniștri de top.

În locul unei teze directe, conform căreia orice guvern al Alianței trebuie respins, vorbitorul folosește procedeul ironiei (a se vedea mimarea bunelor intenții în declarația „Sper”), invocînd un scenariu de farsă, așa-numitul „exercițiu de imagine” conceput de oponenții politici care vor desemna în cele din urmă „adevăratul prim-ministru” și va propune „adevăratul guvern”, „așa cum ne-a promis noi toți”.

Evident, acesta este un scenariu de neconceput, pentru că niciun partid sau vreo alianță nu se sinucide politic propunîndu-i pe cei mai slabi dintre membrii săi după care să vină cu un guvern inatacabil și să spună: ne-am jucat puțin cu așteptările voastre, v-am păcălit, acesta este guvernul real. Nu ar fi aceasta o dovadă a imaturității politice? Ba da, exact asta ar însemna, dar este tocmai convingerea care trebuie transmisă receptorilor.

\section{Alegerile locale din 5 iunie 2016}

Pînă acum am văzut cum politicienii se străduiesc să înlocuiască argumentele cu strategii mai mult sau mai puțin eficiente pentru a convinge alegătorii. În această secțiune voi prezenta pe scurt doar cîteva postere electorale extrem de ridicole ${ }^{22}$. În aceste cazuri este aproape inutil să cauți vreo urmă de relevanță

\footnotetext{
${ }^{21}$ cdep.ro, accesat în 5 septembrie 2017.

${ }^{22}$ Toate posterele analizate se găsesc pe: ziare.com, accesat în 17 august 2017.
} 
comunicativă. Chiar dacă nu își creează sloganurile ei înșiși, este sigur că le acceptă. Aceste sloganuri sînt dovada clară că unii politicieni ar spune orice numai să fie votați.

Primarul Nicolae Stan, candidat al Mișcării Liberale, dorește să obțină un nou mandat cu sloganul „Așa e bine / Să ne ajutăm unii... pe mine!". Punctul de plecare este o expresie standard, a se ajuta unulpe altul. Aici avem o figură de substituție neinspirată (mine în locul lui altul) care are drept rezultat o rimă insignifiantă. Subtextul poate fi: Dă-mi votul tău. Dacă te ajut după asta, văd eu mai tîrziu.

Numele unei candidate la Primăria Municipiului Mioveni devine un substitut de nume şi o parte a sloganului: „Mioveni, numele tău este Argentina!”. Aluzia omofonică este evidentă: prin alegerea acestei doamne, micul oraș Mioveni va fi comparabil cu Argentina (republica [sic!]). La fel de neinspirat este și numele partidului care o susține: Partidul pentru Argeș și Muscel, adică un partid conceput doar pentru un județ și o zonă.

„Evoluție, nu schimbare!” este un alt slogan care generează cel puțin stupefacție. Aici avem o figură retorică ratată, dat fiind că evoluția, conform oricărui dicționar și pentru orice sens al acestui cuvînt, presupune o schimbare.

\section{Concluzii finale}

Fragmentele de discurs și sloganurile analizate reprezintă o mică parte a unui corpus mult mai bogat. Cele mai frecvente strategii retorice și pragmastilistice existente în exemplele prezentate în această lucrare, ca și în celelalte, incluse în corpusul extins, sînt următoarele:

- exploatarea palierului emoțional, în general și în diverse forme;

- enunțurile imperative (frecvent, tipul incitativ);

- argumentul ad hominem (în general, prin parafrază și citare); de asemenea, acest tip de argument este adesea prezent sub forma atacului personal;

- baculinum argumentum - forma brută a atacului personal;

- exclamațiile retorice și întrebările retorice (într-un sens extins, și acestea sînt forme de limbaj vag, mai ales atunci cînd răspunsul nu este cu adevărat implicit în acea întrebare retorică sau vorbitorul nu răspunde el însuși);

- diverse forme de jocuri de cuvinte, exploatîndu-se antonimia, omofonia, aluzia etc.;

- metafora, diverse forme de paralelism morfologic și sintactic;

- diferite forme de limbaj vag (eschivări, cuantificatori vagi, substantive și verbe generale, pronume nedefinite etc.); într-un sens larg, majoritatea figurilor și procedeelor retorico-stilistice aparțin limbajului vag, mai ales atunci cînd acestea trădează într-un fel sau altul condiția persuasivității autentice-aceea de a avea funcție argumentativă, prin susținerea argumentației înseși, nu prin substituirea acesteia.

Conform teoriei relevanței, în cazul discursurilor politice, efectele contextuale sînt obținute în primul rînd prin adăugarea de informații și, de asemenea, prin intensificarea forței cu care se menține o enunțare. În cazul sloganurilor (folosite în mitinguri politice sau în postere electorale), efectele contextuale se obțin în primul rînd prin suprimarea aparentă a informațiilor: sloganurile sînt concise, dar aluzive și foarte incitative. Se pare că dezideratul relevanței este atins în conformitate cu această teorie: efectele contextuale există, astfel încît procesul interpretativ este diminuat.

Cu toate acestea, relevanța enunțărilor de propagandă politică (în principal în campaniile electorale) este grav afectată atunci cînd „o reprezentare mentală” este „interpretată ca reprezentare reală” sau ca „o reprezentare dorită” (Sperber \& Wilson, 1995, p. 232). Aceasta pentru că interpretarea este obținută ca urmare a procedeelor de manipulare retorică—unele mai reduse, altele mai substanţiale.

În primul rînd, dacă ar servi cetățenii, discursurile politice de acest tip ar trebui să fie autentic informative, ceea ce nu exclude expresivitatea și ingeniozitatea. Comunicarea informațiilor trebuie realizată ca o „descriere a unei stări efective” sau ca „o stare de lucruri dorită” (Sperber \& Wilson, 1995, p. 232). Dar cum, din nefericire, platformele politice ale partidelor de astăzi nu sînt consistente, politicienii ascund lipsa de substanță prin strategii insignifiante precum cele menționate, care doar mimează relevanța. 


\section{Bibliografie}

Charaudeau, P. (1983). Langage et Discours, Eléments de sémioliguistique (Théorie et pratique), Hachette, Paris.

Charaudeau, P. (2005). Le discours politique. Les masques du pouvoir, Vuibert, Paris.

Goffman, E. (2007). Viaţa cotidiană ca spectacol, ed. a II-a, comunicare.ro, București.

Green, D.J. (2013). Keeping it Vague: A Study of Vague Language in an American Sign Language Corpus and Implications for Interpreting between American Sign Language and English, Master's Theses, [online].

Ionescu-Ruxăndoiu, L. (2007). Sugestii privind interpretarea pragma-retorică a discursului electoral, în Stan, C., Zafiu, R. \& Nicolae, Al. (eds). Studii lingvistice. Omagiu profesoarei Gabriela Pană Dindelegan, la aniversare, Editura Universității București, București.

Kerbrat-Orecchioni, C. (1980). L'Énonciation. De la subjectivité dans la langage, Armand Colin, Paris.

Mihai, Gh. (1998). Retorica tradițională și retorici moderne, ALL, București.

Quintilian (1974). Arta Oratorică, vol. I., trad. de Maria Hetco, Minerva, București.

Perelman, C. \& Olbrechts-Tyteca, L. (1992). Traité de L'Argumentation. La Nouvelle Rhétorique, ed. a V-a, L'Université de Bruxelles, Bruxelles.

Plett, H.F. (1983). Știința textului și analiza de text, Univers, București.

Sperber, D. \& Wilson, D. (1995). Relevance. Communication and Cognition, Blackwell, Oxford / Cambridge, MA. 